\title{
Hospitality and tourism as a subject in secondary schools: A worthwhile choice or a 'dumping ground'?
}

\section{Helen Andreassen}

Helen worked in the New Zealand wholesale travel sector for 15 years prior to commencing her tertiary teaching career in 2002 with Auckland University of Technology, New Zealand. She is now a senior lecturer and the programme leader for the Bachelor of International Tourism Management. She holds a Bachelor of Tourism Studies (BTS), Certificate in Tertiary Teaching, and Master of Philosophy (First Class Honours) from Auckland University of Technology. Her research interests include tourism education and the perceptions of tourism as a rewarding career, and the changing use of ICT in the tourism industry.

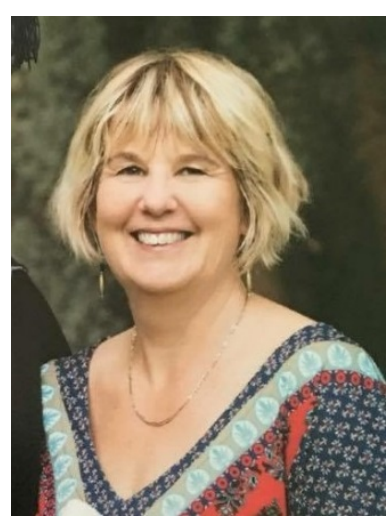

The tourism sector is now New Zealand's number one export earner, contributing 17.4 percent to New Zealand's total exports of goods and services [1]. In addition, the sector directly employs 8.4 percent of New Zealand's workforce and a further 6.1 percent are indirectly employed [2]. Given the obvious importance of hospitality and tourism to both the national economy and local communities, one would expect that a potential career in the industry would be something for a young person to aspire to. Sadly, this is not the case, and recent research has found that much of the poor perception of a career in hospitality and tourism stems from the delivery of hospitality and tourism education in New Zealand secondary schools [3].

In the New Zealand secondary school curriculum, secondary students gain New Zealand's Certificate of Educational Achievement (NCEA) by working towards a combination of achievement or unit standards. The Ministry of Education is the only developer of achievement standards, which are derived from the achievement objectives of the New Zealand Curriculum. Unit standards are developed by industry training organisations [4]. Both hospitality and tourism are deemed to be 'vocational' rather than 'academic' subjects in the NCEA structure and are delivered as unit standards. In a review of the list of approved subjects for University Entrance (UE) in 2011, only subjects delivered as achievement standards were eligible, hence the removal of hospitality and tourism after the revisions came into effect in 2014 [5].

Students are often introduced to the study of hospitality and tourism at secondary school and therefore their early perceptions of a potential career are formed at this stage. These perceptions can be influenced by several factors, including the position that studying hospitality and tourism does not prepare students for further or higher education as effectively as other subjects might. Criticisms of hospitality and tourism as secondary school subjects include that the curriculum lacks both serious and relevant content and academic rigour. The idea that hospitality and tourism classes are used as a 'dumping ground' for the less academically able students is damning. The attitudes of teachers, career advisors, school management and parents also play a significant role in the development of a positive or negative perception of the industry, with some actively discouraging students' interest. The removal of hospitality and tourism as UE approved subjects has only contributed to this poor perception both by students and the larger community, including parents [3]. 
There is an evident disparity between the importance of hospitality and tourism to the economy and local communities, and the perception of a career in the industry. Tourism Industry Aotearoa's People and Skills 2025 report [6] identifies that an extra 36,000 full-time equivalent workers (approx. 47,000 jobs) could be required to service the visitor economy by 2025 . The current delivery of hospitality and tourism education in secondary schools does nothing to enhance the perception of the industry, but instead contributes to its struggle for recognition and credibility. To address this disparity, there is an urgent need for discussion and strategic planning by all stakeholders. The government's current review of the education system, including NCEA, provides this opportunity.

\section{Corresponding author}

Helen Andreassen can be contacted at helen.andeassen@aut.ac.nz

\section{References}

(1) Tourism New Zealand. About the Industry, 2018. https://www.tourismnewzealand.com/about/about-the-industry/ (accessed Mar 8, 2018).

(2) Ministry of Business, Innovation \& Employment (MBIE). New Zealand Tourism Dashboard, 2018. https://mbienz.shinyapps.io/tourism dashboard prod/ (accessed Mar 8, 2018).

(3) Roberts, M. D.; Andreassen, H.; O’Donnell, D.; O’Neill, S.; Neill, L. (2018). Tourism Education in New Zealand's Secondary Schools: The Teachers' Perspective. Journal of Hospitality \& Tourism Education 2018. https://doi.org/10.1080/10963758.2017.1413380

(4) New Zealand Qualifications Authority (NZQA). Standards, 2018. http://www.nzqa.govt.nz/ncea/understanding-ncea/how-ncea-works/standards/ (accessed Apr 26, 2018).

(5) New Zealand Qualifications Authority (NZQA). Processes for Maintaining the Approved Subjects List for University Entrance. http://www.nzqa.govt.nz/qualificationsstandards/awards/university-entrance/processes-for-maintaining-the-approved-subjectslist-for-university-entrance/ (accessed Jun 12, 2018).

(6) Tourism Industry Aotearoa. People \& Skills 2025, 2015. http://www.tourism2025.org.nz/assets/Uploads/People-Skills-2025.pdf (accessed Mar 8, 2018). 